\title{
Rural tourism and its sociocultural impact on the residents of Casacay, El Oro, Ecuador
}

\section{Turismo rural y su impacto sociocultural en los residentes de Casacay, El Oro, Ecuador}

Marjorie Crespo G. ${ }^{1}$, Juan Marco Pupo F. ${ }^{2}$, Jonathan Ruiz C. ${ }^{3}$, Mauricio Noblecilla G. ${ }^{4}$ \& Lilia Ortiz B. ${ }^{5}$

\begin{abstract}
The lack of tourism services in some areas of the country could be explained by the scant attention paid by the competent bodies that must propose and create promotion and entrepreneurship programs in the rural communities to improve tourism services. The central problem of the limited tourism development in Casacay, El Oro, Ecuador, can be addressed with adequate training, taking advantage of the offer presented in this tourist resort and stimulating the entrepreneurial tourism vision in this area. In this study, field work was undertaken relating to the type of tourism and the perspective that the local residents have of the sociocultural impact this can entail. According to the initial diagnosis, the tourists who arrive in the area are seeking sport activities, handicrafts and memories they can gain from their visit, considering the Casacay river to be the major attraction in the area. The residents are at ease with tourism and are very used to it. Nevertheless, the tourism resource has not been sufficiently exploited to drive sustainable local development that can improve the sector and the quality of life of the residents of Casacay.
\end{abstract}

Key words: Rural communities, tourism development, sociocultural impact, sustainable local development.
Resumen. La falta de servicios turísticos en algunas zonas del país podría explicarse por la deficiente atención de los organismos competentes que deben proponery generar programas de fomento y emprendimiento en las comunidades rurales para mejorar la prestación de servicios turísticos. El problema central del limitado desarrollo turístico de Casacay, provincia El Oro, Ecuador, se puede tratar con una adecuada capacitación aprovechando la oferta que se presenta en este balneario turístico e incentivando la visión turística empresarial en esta área. En esta investigación se desarrolló un trabajo de campo relativo al tipo de turismo y la perspectiva que los residentes locales tienen sobre el impacto sociocultural que este puede significar. De acuerdo a un diagnóstico inicial, los turistas que llegan a la zona buscan actividades deportivas, gustan de las artesanías y recuerdos que puedan obtener de su visita, considerando el río Casacay como el mayor atractivo de la zona. Los residentes se sienten a gusto con el turismo y están muy acostumbrados al mismo. Sin embargo, el recurso turístico no se ha explotado lo suficiente para impulsar un desarrollo local sostenible que genere mejoras al sector y a la calidad de vida de los residentes de Casacay.

Palabras clave: Comunidades rurales, desarrollo turístico, impacto sociocultural, desarrollo local sostenible.

\section{(Presentado: $1^{\circ}$ de febrero de 2017. Aceptado: 28 de abril de 2017)}

\footnotetext{
${ }^{1}$ Magíster in Accounting and Auditing. Universidad Técnica de Machala, Ecuador. E-mail: mcrespoqutmachala.edu.ec

${ }^{2}$ Master in Industrial Engineering. Universidad Técnica de Machala, Ecuador. E-mail: jpupoqutmachala.edu.ec

${ }^{3}$ Master in Teaching and Educational Research. Universidad Técnica de Machala, Ecuador. E-mail: jruizqutmachala.edu.ec

${ }^{4}$ Master in Business Administration (in Marketing). Universidad Técnica de Machala, Ecuador. E-mail: jruizqutmachala.edu.ec

${ }^{5}$ Holder of a Superior Diploma. Universidad Técnica de Machala, Ecuador. E-mail: laortizQutmachala.edu.ec
} 


\section{INTRODUCTION}

The comparative advantages offered by the large number of river and beach watering places in El Oro province has generated a diverse offer in tourism services, that have not been able to position themselves in the tourism market for some reasons that we will describe later. The training in tourism of women and men in the rural sector of the El Oro province is carried out through the Ministry of Tourism of Ecuador, under a need generated by the Parish Board or the local municipal government, or directly an association or social group can request training with the purpose of improving tourist services such as: gastronomy, overnight or lodging services, adventure tourism, and about environment preservation, first aid services and tourist protection, among others.

By noting that hotels, restaurants and tourists themselves throw their waste in rivers, lakes and seas, due to the lack of adequate infrastructure, or due to their habitat, tourists contaminate and depredate to a greater or lesser degree, according to their own culture, destroying trees, flora and fauna throwing garbage or waste, thus degrading the landscape and without assuming responsibility for their actions in places that are deteriorated by their own behavior. Due to this, a training project has to be proposed that allows residents of the Casacay parish community to be able to provide gastronomic services, minimizing future damages for the sector, with correct food waste management and helping the tourist to foment the preservation of the environment.

In the rural area, a lot of offers are being generated in the area of tourism, offers such as: rural tourism, adventure, ecological, agritourism and other relative activities. One of the serious problems in the rural area of El Oro is the lack of willingness to collaborate with the communities, carrying out individualistic work, each one works in a disjointed way with local needs. If a training or work is requested in this site, the bureaucratic activities, which sometimes do not attend the regular organ, will be evidenced, through the Parish Board President or the Commune or Site President.

A diagnostic workshop has been created with the Casacay Parish Council to show the needs of this community regarding the weaknesses and strengths of the tourism sector (Table 1). All the natural and cultural resources of Casacay parish encourage a desire to provide the necessary tools to enable its population to promote the tourism development.

TABLE 1. Problems related to the tourism sector perceived by the members of Casacay Parish Council.

$\begin{array}{ll}\text { Problem identification } & \text { Beneficiaries } \\ \text { Lack of recreation centers } & \text { Place residents and Tourists } \\ \text { Lack of Adventure Tourism } & \text { Place residents and Tourists } \\ \text { Lack of Camp Tourism } & \text { Tourists } \\ \text { Lack of food services } & \text { Place residents and Tourists } \\ \text { Lack of hosting services } & \text { Place residents }\end{array}$

Source: Project management team VINCOPP 003-2015. UTMACH. 
Being the case, a considerable tourist affluent, it is viable to implement marketing strategies, without disregard the tourist site image and its promotion (Kim \& Richardson, 2003; Zhang, L’Espoir Decosta, \& McKercher, 2015). The seasons of greatest tourist reception are located on the months January, March, June, July, August and December (Figure 1). The high season is considered the months of June, July and August, due to international visitors (Ministerio de Turismo, 2009). In order to ensure adequate control tourism within a limited area, it is recommendable to handle the indicators Reception Capacity and Rotation Coefficient. In where:

$$
\text { Reception capacity }=\frac{\text { Surface used by tourists }}{\text { Individual average) }}
$$

This is the daily visits average number allowed, and,

Rotation coefficient $=\quad$\begin{tabular}{c}
$\begin{array}{c}\text { Number of daily hours } \\
\text { of opening visits }\end{array}$ \\
\cline { 2 - 2 } Average visit time
\end{tabular}

Where by,

Total daily visits $=$ Reception capacity $*$ Rotation coefficient

The proposal to carry a monitoring of tourism in the studied area is still open, accompanying this document of an environmental management plan.

\section{FIGURE 1. Seasonality of receiver tourism demand 2002-2008.}

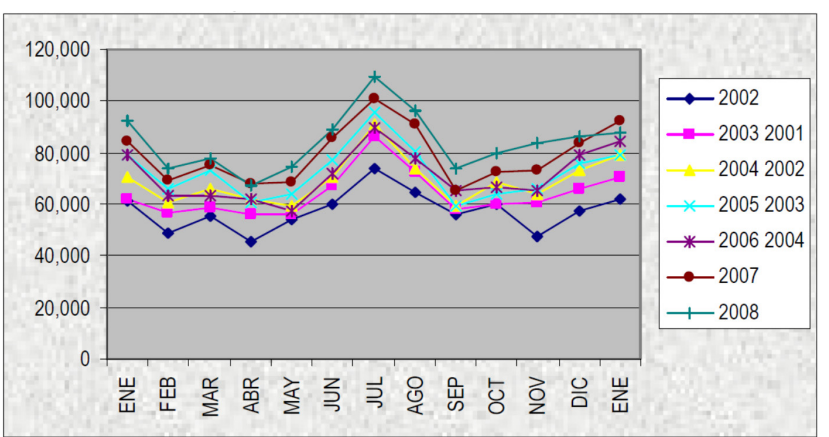

Source: Ministerio de Turismo (2009)

\section{SUPPORT THEORY}

Tourism is understood as a resource with a high content of economic, cultural, social and moral values that produce the satisfaction of the human need for active leisure, and this usually occurs in natural scenarios and the degradation of these spaces can be a big failure for the touristics destinations that allow such degradation (Noblecilla G., Ortíz B., Ruiz C., Encalada L., \& Ordoñez C., 2016). Sustainable rural tourism is the development of small tourism enterprises, or microentrepreneurs, who require a high labor content, generating employment of human resources directly and indirectly managing to strengthen tourism over time. (Martínez Quintana \& Blanco, 2013; Palafox-Muñoz, 2013).

The objective with the present investigation is to analyze the tourist offer quality of the La Cocha recreational center and the diversification alternatives of tourist services provision. To this end, two research instruments, a questionnaire and a survey were developed. The survey elements include different estimation factors that allow the visualization of the reality of tourism from the residents perspective and the possible changes or socio-cultural adaptations, especially those who directly earn income from tourists or activities that they develop during their visit (Jamal \& Getz, 1995; Jonas \& Reza, 2008). One of the typical tourist services is related to gastronomy (Jusoh, Shafiee, \& Jamaluddin, 2012).

\section{METHODOLOGY}

Applied research is exploratory. There are several research techniques and instruments that, when applied, enable the correct identification of the most relevant factors for our study. For the present case, we have used:

- $\quad$ Questionnaire: designed with clear and precise questions that allow the collection of valid information from both the internal (community) and external (visitors) clients. Of these instruments two were applied, to demonstrate the types of services and products demanded by tourists, their hobbies and preferences; also is showed the perception that the local residents have with respect to tourism in the area. 
-

Survey: method to identify the points of interest and concerns of the participants, directly and clearly, based on pre-established options.

The first instrument applied was the questionnaire, as a market study, was directed to potentialize the tourist recreation centers, in this specific case, for the site La Cocha in Casacay parish (see Annexes 1A and 1B). The developed items seek to show the type of tourist that arrives at this destination, their hobbies, preferences and requirements, from the tourist point of view. The detail will be presented as a descriptive statistical summary for each item with its respective graphical representation to visualize the marked trends and facilitate the inference of the results.

In relation to the applied survey, it contains the elements of community perception about tourism (Table 2), the factors analyzed are measured using a Likert-scale survey (Table 3), which allows estimating the trend of the criterion issued by the residents of Casacay parish (Chou, Hsu, \& Chen, 2008; Faulkner \& Tideswell, 1997). For its design, bibliographic databases on tourism in underdeveloped countries were reviewed. Several analyzes have been made, reflecting a low balance of revenues generated by tourism activities (Brohman, 1996; Echtner \& Prasad, 2003; Korstanje, 2016), due to this the need to generate strategies of impulse to the tourist development is created; the expectation is that that does not affect the socio-cultural environment of residents of tourist attractions (Brunt \& Courtney, 1999; McKercher, Wang, \& Park, 2015). The main source of information to determine the incidence of tourism on the socio-cultural development of residents in a sector resides in themselves, which leads us to propose a survey to take socio-cultural impact evidence (Ruhanen, Weiler, Moyle, \& McLennan, 2015).

\section{TABLE 2. Survey elements.}

\section{Item Questioning}

$1 \quad$ Do you believe that tourism has affected the development opportunities of the local community in any way?

2 Do you consider that familiar life is affected by tourism in any way?

3 Is the amount of time that you spend with your family affected in any way during boom tourist seasons?

$4 \quad$ Do you consider that many local residents move to the city in order to find employment?

$5 \quad$ Do you think that community life is affected by tourism in any way?

6 Do you consider that there are resentments between the local community and tourists?

7 Do you think that encounter activities between tourists and local residents can lead to a change in the attitude of local community?

$8 \quad$ Do you think that your way of life is temporarily altered during the tourism season?

9 Do you think that as a result of tourism, local development is more in the interest of visitors as opposed to local residents?

10 Do you consider that local people change their behavior to emulate the behavior of tourists?

11 Do you feel that your safety is affected during the tourist season in any way?

12 Why do you reside in this community?

Source: Brunt \& Courtney (1999). Edition: The author.

TABLE 3. Weightings to tabulate the surveys.

\begin{tabular}{lcc}
\hline Weighing & Likert Scale & Open question \\
\hline Totally disagree & 1 & - \\
In disagreement & 2 & - \\
Neutral & 3 & - \\
Agree & 4 & - \\
Totally agree & 5 & - \\
Taste for nature & - & 1 \\
Birthplace & - & 2 \\
Workplace & - & 3 \\
Like the community environment & - & 4
\end{tabular}

Source: Brunt \& Courtney (1999), and Faulkner \& Tideswell (1997). Edition: The author. 


\section{RESULTS}

The managements began with an assessment of tourists' types, their needs around the area's own tourism environment, and later to evidence the community perception about visitors within the community and their impact on local tourism development. The initial research was done to analyze the type of tourists who arrive in the area, their hobbies and preferences, services and tourist products mainly demanded, among other elements that reflected their results to be socialized with the Casacay Parish Council members and residents of bordering sectors of watering place La Cocha. This information is basic for the development of training workshops on working skills for tourism service providers within the mentioned sector.

According to the questionnaire applied, when defining the typical tourist that arrives at the site La Cocha of Casacay parish (see Annex 2), it is evident that most of the external tourists come from Cuenca city (32.6\%) and in smaller proportion from Machala. The internal tourism is estimated with $21.6 \%$ of people coming from Pasaje city. The people who visit this place are mostly traders $(28.4 \%)$ and students (21.6\%), being low the presence of other professionals. It should be noted that for the collection of this information, residents of the area and traders working within the sector both were not included. And although there is a slight greater presence of male gender (56\%), the circulation of tourists returning to the area (72\%) is evenly distributed, with a typical period of between one and three times a year, according to $64 \%$ of the tourists consulted.

The season of greatest circulation occurs in the months in which the people have school holidays and in the summer season (adding 64\%); This includes the months of February, March, July and even August, although Carnival week is not necessarily the favorite time for tourists (according to their own criteria). This latest fact may be due to the fact that at this time internal tourism is intensifying. Something remarkable is that the tourists are arriving accompanied by their family; According to $65 \%$ this site is conducive to healthy family entertainment; they usually arrive to the place in their own vehicles (60\%) given the ease of parking in the large spaces for this purpose that are near to watering place La Cocha.

The estimated budget for the visit is between 20 and 100 dollars, according to $76 \%$ of the tourists interviewed. Typical expenses are about food and drinks. People who come to the area are in the age range between 26 and 45 years (57\%), that is, they are relatively young people. Usually, they do not need housing (77\%), or at least they do not require a hotel or hostel according to $80 \%$ of the tourists, since they visit the place one or two days, considering that these days are the weekends (Saturdays and Sundays). The aim is to spend the day in family during those days or during their holidays (77.9\%) in this destination, chosen essentially for their tranquility, where people seek to relax and enjoy the sector landscapes (according to $83.2 \%$ of the Consulted).

Tourists arriving in the area propose the organization of sports activities. According to $50 \%$ of respondents this could improve their stay. To a lesser extent proposals were made for live music, recorded or enlivened by music mixers. One complement in services would be the adaptation of more sanitary batteries and fun places like discotheques and karaokes, according to the opinion of $37.9 \%$ tourists. However, we must consider that this information is very varied, but not the proposed tourist products, which are crafts and souvenirs of the sector; $70 \%$ of tourists would like this site to promote these products. In those art, one can consider that the most outstanding of the area is the river Casacay and its surroundings landscapes, from the perspective of $56.3 \%$ of the visitors; an amount that could rise above $70 \%$ because those who highlight the tranquility of the area could also share this view. In contrast, the presence of pests such as mosquitoes and weeds often discourages tourists from visiting the area. $38.9 \%$ of visitors consider that these problems are the main obstacle to overcome to promote the sustainable tourism development on this popular place.

According to the results of the survey, summarized in Table 4, we can see that tourism has not had a notable or significant impact on the development opportunities of the local community; community residents consider that habitual family life is not affected by tourism in any way; likewise, the time that the members of this community dedicate to their families is not affected during the seasons considered high for tourism. It is estimated that most of the residents who migrate to the city do in order to find employment; the community life or social coexistence with other residents is not affected by tourism in any way. There is no or no evidence of any kind of resentment between the local community and the tourists; in this respect, residents are interested in the encounter activities between tourists and members of this community, although they are neutral about the idea or need to generate a change in the attitude of this population. 
It was also observed that the lifestyle of the local people suffers a low impact during the tourist season, without perceiving counterproductive changes; as a result of tourism, and specifically tourism potential, local development is interesting for both visitors and the local community. Residents rarely change their behavior to emulate some ones of tourists; they also consider that their safety and that of their family is not affected during the tourist season in any way; and usually the people who live in this sector do so because it is their birthplace or origin, theirs or of their ancestors, and they have bequeathed this place of residence for them. Among the most influential factors on the local population is the time spent by residents with their families during the high tourist seasons (June, July and August), which they also see as unaffected for it.

\section{TABLE 4. Basic descriptive statistical elements.}

\begin{tabular}{|c|c|c|c|}
\hline Questioning & Modal & Median & S.D. \\
\hline $\begin{array}{l}\text { Do you believe that tourism has affected the development opportunities } \\
\text { of the local community in any way? }\end{array}$ & 2 & 2 & 1.37 \\
\hline Do you consider that familiar life is affected by tourism in any way? & 2 & 2 & 1.28 \\
\hline $\begin{array}{l}\text { Is the amount of time that you spend with your family affected in any } \\
\text { way during boom tourist seasons? }\end{array}$ & 2 & 2 & 1.20 \\
\hline Do you consider that many local residents move to the city in order to find employment? & 4 & 4 & 1.30 \\
\hline Do you think that community life is affected by tourism in any way? & 2 & 2 & 1.39 \\
\hline Do you consider that there are resentments between the local community and tourists? & 2 & 2 & 1.14 \\
\hline $\begin{array}{l}\text { Do you think that encounter activities between tourists and local } \\
\text { residents can lead to a change in the attitude of local community? }\end{array}$ & 3 & 3 & 1.40 \\
\hline Do you think that your way of life is temporarily altered during the tourism season? & 2 & 2 & 1.25 \\
\hline $\begin{array}{l}\text { Do you think that as a result of tourism, local development is more in the interest } \\
\text { of visitors as opposed to local residents? }\end{array}$ & 3 & 3 & 1.40 \\
\hline Do you consider that local people change their behavior to emulate the behavior of tourists? & 2 & 2 & 1.23 \\
\hline Do you feel that your safety is affected during the tourist season in any way? & 2 & 2 & 1.41 \\
\hline Why do you reside in this community? & 2 & 2 & 0.94 \\
\hline
\end{tabular}

\section{CONCLUSIONS AND RECOMMENDATIONS}

The tourism characterization shows that the visitors are relatively young people, merchants and students who take advantage of the weekends and holiday period to visit this tourist destination. Usually, visitors arrive in their own vehicles, which is why special attention should be paid to safety for these vehicles and their occupants. To requesting the adaptation of more sanitary batteries and their frequent maintenance, is one of the main necessities of the tourists, and also the presence of artisans who make memories about the place that stands out, according to the opinion of the tourists themselves, by landscapes that include Casacay River. And although the weeds and pests carried by these are a nuisance for many tourists, the sector remains a point of visit of great competition, especially for people arriving from Cuenca to El Oro province and choose to stay in the watering place La Cocha.
Regarding the socio-cultural impact of tourism from perspective of Casacay parish residents we have been able to show that tourism has not altered the time that the residents dedicate to their respective homes, their habitual family life, nor their lifestyle in the community. Development opportunities remain intact due to the low impact that tourism has on the sector analyzed, this is reflected in the absence of rivalries or resentments between residents and visitors. In addition, the population is mostly native to the area, which maintains its habitat as its generations pass.

There is a great incidence in the economic and tourist development, which facilitates the strengthening of the local sustainable development of Casacay parish. In order to improve the quality of the tourist offer in the recreational center La Cocha, in Casacay parish on Pasaje city, it is 
initially necessary to know the specific needs and the current reality regarding these points, for this reason there is a required to train in the provision of Gastronomic services to the small shopkeepers of the La Cocha Recreation Center, because a resource poorly exploited on the site is due its poor gastronomy (according to the tourists opinion).

The quality improvement in the tourist offer in La Cocha recreational center depends on the residents of the area basically, so it would be very useful practical workshops with visualization of examples on local development driven in other sectors. The emulation of certain activities could be useful and as an inducement to new ideas and proposals for joint cooperation. Regarding this type of collaborative work, the residents are interested in the local tourist development, due to the high number of people who benefit directly or indirectly from the tourist activities that are presented in this sector.

It is suggested to keep the attention in the training to local people and entrepreneurs, especially in the gastronomic area, that can later be diversified to cover other aspects. The common objective is the same, sustainable local development, which will allow sustainability in the tourism strengthening processes and will enable many other ideas and facilitate obtaining external investment (if it's required).

Finally, it is important to recognize that the site has sufficient potential to seek agreements with local, regional and national tourism operators. It would be feasible from different perspectives, its landscapes, geographical location, ease of access, diversity in flora, local climate, harmony between residents and visitors, among other elements that make this sector a point to consider for tourists that love natural areas.

\section{REFERENCES}

Andereck, K.L., Valentine, K.M., Knopf, R.C., \& Vogt, C.A. (2005). Residents' perceptions of community tourism impacts. Annals of Tourism Research 32, 4, 1056-1076.

Asociación de Juntas Parroquiales Rurales de El Oro. (2010). Plan Parroquial de Casacay 2010-2025. Plan de Desarrollo Estratégico. Pasaje, El Oro, Ecuador: Gobierno Parroquial Autonómo de Casacay.

Bramwell, B. (2015). Theoretical activity in sustainable tourism research. Annals of Tourism Research 54, 204-218.

Brohman, J. (1996). New directions in tourism for Third World development. Annals of Tourism Research 23, $1,48-70$
Brunt, P., \& Courtney, P. (1999). Host perceptions of sociocultural impacts. Annals of Tourism Research 26, 3, 493-515.

Chou, T.Y., Hsu, C.L., \& Chen, M.C. (2008). A fuzzy multi-criteria decision model for international tourist hotels location selection. International Journal of Hospitality Management 27, 2, 293-301.

Echtner, C.M., \& Prasad, P. (2003). The context of third world tourism marketing. Annals of Tourism Research 30, 3, 660-682.

Faulkner, B., \& Tideswell, C. (1997). A framework for monitoring community impacts of tourism. Journal of Sustainable Tourism 5, 1, 3-28.

Jamal, T.B., \& Getz, D. (1995). Collaboration theory and community tourism planning. Annals of Tourism Research 22, 1, 186-204.

Jonas, S.H., \& Reza, B. (2008). Hospitality studies and hospitality management: A symbiotic relationship. International Journal of Hospitality Management 101, 8357-8361.

Jusoh, Z., Shafiee, N.H., \& Jamaluddin, A. (2012). Factors influencing tourist food consumption. International Journal of Hospitality Management, 1-27.

Kim, H., \& Richardson, S.L. (2003). Motion picture impacts on destination images. Annals of Tourism Research 30, 1, 216-237.

Korstanje, M.E. (2016). Sun \& sea tourism: Fantasy and finance of the all-inclusive industry. Annals of Tourism Research 58, 178-180.

Martínez, V., \& Blanco, R. (2013). Hacia una gestión sostenible de las actividades turísticas en los espacios rurales y naturales. RIO: Revista Internacional de Organizaciones 10, 131-155.

McKercher, B., Wang, D., \& Park, E. (2015). Social impacts as a function of place change. Annals of Tourism Research 50, 52-66.

Noblecilla, M., Ortíz, L., Ruiz, J., Encalada, l., \& Ordoñez, O. (2016). Análisis del potencial turístico de las comunidades rurales. Caso de estudio: Comunidad Muyuyacu, El Oro-Ecuador. RIAT 12, 48-59.

Palafox-Muñoz, A. (2013). El turismo como eje de acumulación. Especial: América Latina. América Latina, 161-174.

Ruhanen, L., Weiler, B., Moyle, B.D., \& McLennan, C.J. (2015). Trends and patterns in sustainable tourism research: a 25-year bibliometric analysis. Journal of Sustainable Tourism 23, 4, 517-535.

Zhang, C.X., L’Espoir Decosta, P., \& McKercher, B. (2015). Politics and tourism promotion: Hong Kong's myth making. Annals of Tourism Research 54, 156-171. 